\title{
Kontribusi dan Status Wanita dalam Usaha Peternakan Sapi Potong
}

\author{
Contribution and Status of Women in Beef Cattle Production
}

\author{
Urip Santoso dan Kususiyah
}

\author{
Jurusan Peternakan, Fakultas Pertanian, Universitas Bengkulu \\ Jln. Raya Kandang Limun, Bengkulu \\ Email: uripsantoso60@gmail.com
}

\begin{abstract}
The purpose of the present study is to evaluate the contribution and status of women in beef cattle production. This experiment was conducted in two villages, Kota Argamakmur, North Bengkulu in which 50 households were selected in each village and devided into two groups of production scale namely small scale (1-5 beef cattle) and middle scale (6-10 beef cattle). The contribution of women in small scale was 1.177 hours per day whereas in middle scale was 2.388 hours. On the other hand, the contribution of man in small scale was 2.355 hours per day whereas in middle scale was 2.655 hours. Although the contribution of women was relatively high, the status was still lower. This was indicated by lower decision making for women in important activities. Family activities was still dominated by women. The contribution of women in small scale was 5.889 hours per day whereas in middle scale was 0.087 hour. This fact showed that although the contribution of women in middle scale was relatively similar to man, the contribution of women in family activities was not changed. The decision making in family for an important activities was still dominated by man, whereas the regulat activities was still dominated by women.
\end{abstract}

Key words: women contribution, woman status, beef cattle production

\begin{abstract}
ABSTRAK
Peneltian ini bertujuan untuk mengevaluasi kontribusi dan status wanita dalam usaha sapi potong. Penelitian ini dilakukan di dua desa di kecamatan Kota Argamakmur, Bengkulu Utara dan masing-masing desa dipilih responden yang mempunyai sapi potong skala kecil (1-5 ekor) dan skala menengah (6-10 ekor). Dari setiap desa diambil responder sebanyak 50 keluarga dimana pada setiap desa terbagi atas 25 responden usaha skala kecil dan 25 responden usaha skala menengah. Hasil penelitian menunjukkan bahwa jam kerja wanita pada usaha sapi potong untuk skala kecil adalah 1,177 jam per hari, sedangkan pada skala menengah adalah 2,388 jam per hari. Sementara jam kerja pria untuk skala kecil adalah 2,355 jam sedangkan pada skala menengah adalah 2,655 jam. Walaupun kontribusi wanita cukup besar, namun statusnya dalam usaha sapi potong masih belum dianggap sebagai mitra kerja. Kegiatan koperasi dan penyuluhan dominasi pria juga masih sangat besar. Kegiatan rumah tangga masih didominasi oleh wanita. Jam kerja wanita pada rumah tanggal untuk skala kecil adalah 5,889 jam per hari sementara pria hanya 0,282 jam. Pada skala menengah, jam kerja wanita pada rumah tangga adalah 6,402 jam sedangkan pria hanya 0,087 jam. Yang menarik adalah walaupun jam kerja wanita pada usaha sapi potong skala menengah adalah relatif sama dengan pria, namun jam kerjanya dalam rumah tangga tidak berkurang. Pola pengambilan keputusan dalam rumah tangga juga sangat didominasi oleh pria terutama pada hal-hal yang dianggap penting, sedangkan untuk kegiatan rutin rumah tangga keputusan diambil oleh wanita.
\end{abstract}

Kata kunci: kontribusi wanita, status wanita, usaha sapi potong

\section{PENDAHULUAN}

Telah lama diketahui bahwa peranan wanita di sektor pertanian dan dalam menunjang keberhasilan suatu usaha skala keluarga sangat besar. Hugeng (2011) melaporkan bahwa kontribusi wanita dalam pendapatan keluarga sebesar $21,87 \%$, sedangkan pekerjaaan yang dilakukan secara bersama dengan suami memberikan kontribusi sebesar 49,6\%. Selanjutnya dinyatakan bahwa alokasi waktu kerja wanita transmigrasi di perusahaan kelapa sawit relatif sama 
dengan suami yaitu 7 jam per hari, sedangkan usaha tani di lahan sendiri adalah 4 jam 10 menit per hari. Menurut Sajogyo (1983, 1984) dan Wahyuni (1983) wanita memgang peranan yang penting dalam usaha peternakan. Menurut Wisadirana (1986) pada peternakan sapi perah di Pujon, rata-rata curah kerja wanita per hari hanya sedikit berbeda dengan pria yaitu 3,5 jam sementara pria 4,6/hari. Gusmaniar (2013) melaporkan bahwa kontribusi wanita peternak kelinci sebesar $55-70 \%$ dari total pendapatan keluarga. Kontribusi pendapatan nelayan dari pendapatan usaha nelayan terhadap pendapatan keluarga yang bekerja sebagai nelayan dapat dihitung yaitu kategori atau ukuran besar kontribusi dapat diinterpretasikan sebagai berikut: rendah $(0 \%$ - 33.3\%), sedang $(33,4 \%-66,6 \%)$, dan tinggi $(66,7 \%-100 \%)$. Dengan demikian diambil kesimpulan, bahwa kontribusi pendapatan nelayan terhadap pendapatan keluarga memiliki kontribusi sedang, yaitu 40,46\% (Kumala, 2011). Rata-rata pendapatan rumah tangga petemak sapi perah sebesar Rp 15 juta per tahun, sedangkan kebutuhan hidup layak penduduk di Kabupaten Boyolali pada tahun 2007 sebesar Rp 658 ribu per kapita per bulan atau sekitar Rp 31 juta per rumah tangga per tahun. Usaha sapi perah memberikan kontribusi sekitar $15 \%$ terhadap total pendapatan rumah tangga atau terbesar ketiga setelah usaha dan buruh non pertanian (Utomo et al., 2007). Puspitawati et al. (2012) melaporkan bahwa kontribusi ekonomi wanita terhadap pendapatan keluarga adalah sebesar $51 \%$.
Jadi, wanita sangat berperan dalam meningkatkan pendapatan keluarga. Namun demikian, peningkatan SDM wanita seringkali lepas dari pengamatan pengambil kebijaksanaan. Sebagai contoh, setiap ada kegiatan penyuluhan, demplot dll. wanita jarang sekali dilibatkan, sehingga pengetahuan dan keterampilannyapun tidak berkembang. Kondisi ini akan menghambat usaha peningkatan produksi yang pada gilirannya menekan keuntungan yang diperoleh peternak serta menghambat usaha pemenuhan target kebutuhan daging nasional.

Bengkulu sesuai dengan keadaan alamnya amat sesuai dengan peternakan sapi potong. Untuk mengembangkan usaha ini, maka di daerah-daerah transmigrasi mulai dikembangkan usaha sapi potong oleh instansi terkait. Mulai tahun ini, Bengkulu melakukan proyek pembibitan sapi potong ditingkat peternak melalui program Gerakan Pengembangan Sentra Pembibitan Pedesaan (Gerbang Serba Bisa, GSB) di daerah transmigrasi Argamakmur Bengkulu. Usaha ini dilakukan untuk mengembangkan populasi sapi potong yang dirasa masih sangat kurang untuk memenuhi kebutuhan daging di Propinsi Bengkulu. Usaha lain yang dilakukan untuk pengembangan produksi sapi potong adalah melalui program IFAD kepada peternak dengan sistem bagi hasil. Sementara itu, untuk meningkatkan kualitas reproduksi sapi potong dikembangkan pula kantong-kantong Inseminasi Buatan. Bahkan uji coba embrio transfer telah dilakukan, walaupun 
hasilnya kurang memadai. Sejauh mana keberhasilan program-program tersebut masih belum banyak diteliti. Lebih jauh lagi, seberapa jauh kontribusi dan status wanita dalam menyukseskan programprogram tersebut, pada umumnya dan ditingkat peternakan keluarga sapi potong belum diperoleh datanya. Pengembangan sapi potong di Bengkulu di tingkat peternak tampaknya juga belum melibatkan wanita sebagai partner kerja/bisnis. padahal dalam usaha peternakan sapi potong wanita memegang peranan yang cukup penting. Hal ini diketahui dari pengamatan sekilas di kantong-kantong produksi. Sebagai contoh mereka belum dilibatkan dalam kegiatan penyuluhan, demplot, dan lain-lain. Berdasarkan pemikiran tersebut, maka perlu dilakukan penelitian tentang seberapa jauh kontribusi dan status wanita dalam rumah tangga dan usaha sapi potong serta faktor-faktor yang mempengaruhi kondisi dimana wanita belum dilibatkan sebagai mitra kerja serta alternatif penanggulangannya.

\section{METODE PENELITIAN}

Metode pendekatan yang digunakan sebagai alat analisis adalah struktural fungsional (Levy, 1971), sebab dengan menggunakan pendekatan ini akan dilihat hubungan pria dan wanita dalam kelompok rumah tangga.

Penelitian dilakukan di Kecamatan Argamakmur, Kabupaten Bengkulu Utara. Pemilikan sampel dilakukan secara sengaja dengan pertimbangan
1. Desa tersebut merupakan kantong produksi sapi potong dan sebagai model proyek Gerbang Serba Bisa pembibitan dan produksi sapi potong.

2. Sebagai populasi adalah semua peternak sapi potong di desa-desa di Kecamatan Argamakmur, Bengkulu Utara. Sebagai unit analisis adalah rumah tangga.

Pemilihan lokasi dilakukan secara sengaja dengan pertimbangan bahwa pelaksanaan Gerbang Serba Bisa dilaksanakan di Kecamatan Argamakmur, Bengkulu Utara. Sampel akan dipilih secara acak berstrata tidak berimbang dimana dalam satu kecamatan akan ditetapkan sebanyak 2 (dua) desa. Dari setiap desa akan diambil sampel sebanyak 50 rumah tangga peternak.

Tahap-tahap penentuan kriteria sampel dilakukan dengan cara sebagai berikut.

a. Tahap pertama menggunakan pencacahan lengkap terhadap populasi, sehngga diperoleh informasi dasar identitas reponden, luas penguasaan lahan dan jumlah penguasaan sapi potong.

b. Tahap kedua dilakukan pengklasifikasian dengan cara mengelompokkan peternak ke dalam 2 lapisan berdasarkan skala kepemilikan.

1. Kepemilikan ternak antara 5-10 unit ternak (skala menengah). 
2. Kepemilikan ternak antara kurang dari 5 unit ternak (skala kecil).

Pengambilan data sekunder melalui instansi terkait dengan penelitian ini. Pengumpulan data primer dilakukan melalui wawancara dengan responden dengan menggunakan daftar pertanyaan yang telah tersedia dan dilakukan pada pengumpulan langsung.

Daftar pertanyaan yang digunakan dengan metode recall (mengingat kembali) terhadap suatu kejadian dengan menekankan reference period (daya ingat) satu hari yang lalu dan sebulan yang lalu menurut petunjuk Wigna et al. (1980).

Adapun peubah yang diukur adalah pola pekerjaan mengurus rumah tangga, pola kerja wanita di bidang usaha sapi potong, pola pekerjaan mencari nafkah, pola pengambilan keputusan suami-isteri dalam rumah tangga, seperti pola pengambilan keputusan suami-isteri dalam urusan rumah tangga, pola pengambilan keputusan pada kegiatan sapi potong, pola pengambilan keputusan pada kegiatan koperasi dan penyuluhan peternakan sapi potong.

\section{HASIL DAN PEMBAHASAN}

\section{Curahan Kerja Usaha Sapi Potong}

Curahan kerja wanita dan pria sehari-hari pada usaha sapi potong tertera pada Tabel 1.

Tabel 1. Jam kerja rutin pria dan wanita pada usaha Sapi Potong (jam/hari)

\begin{tabular}{lcccc}
\hline \multirow{2}{*}{ Jenis Pekerjaan } & \multicolumn{2}{c}{ Skala Kecil } & \multicolumn{2}{c}{ Skala Menengah } \\
\cline { 2 - 5 } & Pria & Wanita & Pria & Wanita \\
\hline Mencari rumput & 0,846 & 0,449 & 1,062 & 0,945 \\
Memotong rumput & 0,343 & 0,132 & 0,424 & 0,367 \\
Memberi pakan dan minum & 0,250 & 0,212 & 0,333 & 0,317 \\
Membersihkan kandang & 0,236 & 0,051 & 0,282 & 0,176 \\
Menggembalakan sapi & 0,680 & 0,333 & 0,554 & 0,583 \\
Jumlah & 2,355 & 1,177 & 2,655 & 2,388 \\
\hline
\end{tabular}

Pada tabel tersebut dapat dilihat bahwa jam kerja wanita pada usaha sapi potong 1.177 dan pria 2,355 jam per hari untuk skala usaha kecil (1-5 ekor). Atau menempati 33,3\% jam kerjausaha sapi potong untuk wanita dan $66,7 \%$ untuk pria. Untuk skala usaha menengah (6-10 ekor) jam kerja wanita 2.388 dan pria 2.655 jam kerja per hari. Atau menempati 47,4\% untuk wanita dan $52,6 \%$ untuk pria. Jika kita lihat, maka jam kerja wanita pada skala menengah ternyata mengalami lonjakan yang sangat tinggi dari 1.177 jam untuk skala kecil menjadi 2.388 jam pada skala menengah (103\%) mendekati jam kerja pria, sementara jam kerja pria relatif hampir sama antara skala menengah dan kecil. Ini menunjukkan bahwa untuk pekerjaan yang bersifat rutin pada usaha sapi potong kontribusi wanita adalah seimbang dengan pria pada skala usaha menengah. Pria selain bekerja pada usaha sapi potong mempunyai pekerjaan lain yang bahkan dianggap sebagai usaha 
utama yaitu bertani (bersawah dan berkebun). Oleh karena itu, pada saat pekerjaan sapi potong memerlukan waktu yang lebih banyak, sebagian pekerjaan jatuh ke tangan wanita yang lebih sering tinggal di rumah. Yang menarik adalah bahwa kegiatan menggembalakan sapi, mencari rumput dan memberi pakan dan minum sapi pada skala usaha menengah dilakukan oleh pria dan wanita pada proporsi yang relatif hampir sama. Mengembalakan sapi dan mencari rumput biasanya dilakukan oleh pria. Ini menunjukkan adanya perubahan "budaya" yang beranggapan bahwa pekerjaan yang kasar dan berat secara fisik dilakukan oleh pria ke pola kebiasaan pekerjaan kasar juga dapat dilakukan oleh wanita.

\section{Pelaksana Pekerjaan Rutin Usaha Sapi Potong}

Tabel 2 menunjukkan kontribusi pekerja wanita dan pria (dalam persen) untuk masing-masing jenis kegiatan usaha sapi potong. Secara umum kegiatan sapi potong ini dilakukan secara bersama-sama $(47,44 \%)$, baru disusul dikerjakan sendiri oleh pria saja $(40,45 \%)$ dan wanita saja $(12,11 \%)$ untuk skala usaha kecil. Pada skala usaha menengah, terlihat bahwa usaha sapi potong sebagian besar dilakukan bersama-sama $(68,25 \%)$, pria saja hanya $29,80 \%$ dan wanita saja $1,94 \%$. Dari data tersebut dapat disimpulkan bahwa kegiatan rutin sapi potong dilakukan secara bersama-sama lebih banyak pada usaha sapi potong tingkat menengah daripada pada skala kecil. Pada skala kecil didominasi pria masih cukup banyak $(40,45 \%)$, sementara pada kegiatan yang dilakukan secara bersama sebesar $47.44 \%$.

Tabel 2. Pelaksana pekerjaan pada usaha sapi potong (\%)

\begin{tabular}{lcccccc}
\hline Jenis Pekerjaan & \multicolumn{3}{c}{ Skala kecil } & \multicolumn{3}{c}{ Skala menengah } \\
\cline { 2 - 7 } & $\mathrm{P}$ & $\mathrm{W}$ & $\mathrm{P}+\mathrm{W}$ & $\mathrm{P}$ & $\mathrm{W}$ & $\mathrm{P}+\mathrm{W}$ \\
\hline Mencari rumput & 40,29 & 8,96 & 50,75 & 27,27 & 0,00 & 72,72 \\
Memotong rumput & 46,30 & 11,11 & 42,59 & 28,12 & 0,00 & 71,88 \\
Memberi pakan -minum & 20,89 & 11,94 & 67,16 & 18,18 & 3,03 & 78,79 \\
Membersihkan kandang & 59,70 & 7,46 & 32,83 & 45,45 & 0,00 & 54,54 \\
Menggembalakan sapi & 35,09 & 21,05 & 43,86 & 30,00 & 6,67 & 63,33 \\
Rata-rata & 40,45 & 12,11 & 47,44 & 29,80 & 1,94 & 68,25 \\
\hline
\end{tabular}

$\mathrm{P}=$ Pria, $\mathrm{W}=$ wanita, $\mathrm{P}+\mathrm{W}=$ dikerjakan oleh pria dan wanita

Yang menarik adalah bahwa pada usaha skala menengah, wanita sangat kecil prosentasenya mengerjakan kegiatan usaha sapi potong secara mandiri yaitu $1.94 \%$ saja. Pada skala usaha kecil pengerjaan secara mandiri oleh wanita lebih besar yaitu $12.11 \%$. ini barangkali menunjukkan bahwa wanita masih belum dipercaya untuk secara mandiri mengerjakan usaha sapi potong. Atau wanita belum berani memikul kerja secara mandiri. Hal ini tercermin manakala usaha sapi potong berkembang dan memerlukan tanggung jawab yang lebih tinggi, persentase wanita yang bekerja secara mandiri menyusut. Ini barangkali berkaitan erat dengan budaya 
"kanca wingking" dimana wanita dianggap membantu pekerjaan pria daripada dianggap sebagai mitra kerja. Berdasarkan curahan kerjanya wanita mempuyai peranan penting dalam usaha sapi potong. Menurut Alatas (1990) peningkatan partisipasi wanita dalam kegiatan ekonomi oleh karena masyarakat menyadari bahwa pendidikan sama pentingnya bagi kaum wanita agar dapat berpartisipasi dalam pembangunan. Selain itu, kemauan wanita untuk mandiri dan berusaha membiayai kebutuhan hidupnya dan juga membantu kebutuhan hidup anggota keluarganya. Hal lain yang mendorong wanita untuk terjun ke pasar kerja adalah semakin luasnya kesempatan kerja sebagai kerajinan tangan. Pendapatan pekerja wanita dipengaruhi oleh jam kerja dari pekerja wanita untuk bekerja. Jam kerja berpengaruh terhadap pendapatan wanita dalam perekonomian rumah tangga. Semakin lama jam kerja wanita, maka semakin banyak hasil yang diterima sehingga kebutuhan keluarga bisa terpenuhi (Larasati, 2003). Mahdalia
(2012) melaporkan bahwa curahan waktu kerja perempuan pada usaha peternakan sapi potong di Kelompok Tani Ternak Lonrae sebanyak 3,675 jam/hari atau sebesar 59,34\%.

Annisawati et al. (2014) melaporkan bahwa kontribusi tenaga kerja perempuan pada usaha sapi Jabres di Kabupaten Brebes sebesar 40,43\%. Faktor jumlah kepemilikan ternak, jumlah anggota keluarga, umur tenaga kerja perempuan dan pola pemeliharaan berpengaruh terhadap kontribusi tenaga kerja perempuan. Lestariningsih et al. (2008) melaporkan bahwa curahan kerja wanita pada sapi perah sebesar 1-2 jam per hari sementara pria 2-4 jam per hari. Jadi, kontribusi wanita terhadap pendapatan keluarga tidak lagi diragukan sebagaimana hasil penelitian Fatmawati (2011) dan Gusmaniar (2013).

\section{Kegiatan Usaha Sapi Potong yang Tidak Rutin}

Tabel 3. Pola pengambilan keputusan pada usaha sapi potong yang tidak rutin (\%)

\begin{tabular}{lcccccc}
\hline \multirow{2}{*}{\multicolumn{1}{c}{ Jenis Pekerjaan }} & \multicolumn{3}{c}{ Skala kecil } & \multicolumn{3}{c}{ Skala menengah } \\
\cline { 2 - 7 } & $\mathrm{P}$ & $\mathrm{W}$ & $\mathrm{P}+\mathrm{W}$ & $\mathrm{P}$ & $\mathrm{W}$ & $\mathrm{P}+\mathrm{W}$ \\
\hline Membantu kelahiran & 44,07 & 15,59 & 40,34 & 78,79 & 0,00 & 21,21 \\
Membantu kandang & 64,18 & 0,00 & 35,82 & 43,75 & 0,00 & 56,25 \\
Pemeliharaan rumput & 14,63 & 24,39 & 60,98 & 16,67 & 0,00 & 83,33 \\
Pembelian sapronak & 66,67 & 0,00 & 33,33 & 60,61 & 0,00 & 39,39 \\
Pemeriksaan kesehatan & 60,29 & 2,81 & 36,77 & 68,75 & 0,00 & 31,25 \\
Pemeriksaan kebuntingan & 84,85 & 1,79 & 13,36 & 78,13 & 0,00 & 21,88 \\
Pembelian bibit & 50,00 & 0,00 & 50,00 & 37,50 & 0,00 & 62,50 \\
Mengawinkan sapi & 64,18 & 10,45 & 25,37 & 69,70 & 0,00 & 30,30 \\
Penjualan sapi & 23,68 & 0,00 & 76,32 & 18,52 & 0,00 & 81,48 \\
Rata-rata & 52,51 & 6,12 & 41,37 & 52,49 & 0,00 & 47,51 \\
\hline P= Pria, W = wanita, P+W = dikerjakan oleh pria dan wanita
\end{tabular}

Tabel 3 menunjukkan kegiatan usaha sapi potong yang tidak rutin tetapi sangat menentukan kegiatan usaha sapi potong terlihat bahwa pada kegiatan ini 
pola pengambilan keputusan masih sangat didominasi oleh pria baik pada usaha skala kecil maupun skala menengah masingmasing 52,51\% dan 52,49\%, sedangkan yang dilakukan oleh wanita secara mandiri masih relatif rendah $(6,12 \%$ dan $0 \%$ untuk skala kecil dan menengah).

Sementara pola pengambilan keputusan yang dilakukan secara bersama atau bermusyawarah relatif lebih rendah daripada yang diputuskan oleh pria secara mandri $(41,37 \%$ untuk skala kecil dan $47,51 \%$ untuk skala menengah). Hasil wawancara menunjukkan bahwa walaupun terjadi musyawarah, pada kenyataannya keputusannyapun lebih banyak didominasi oleh pria. Mengingat jenis-jenis kegiatan tersebut sangat menentukan keberhasilan usaha sapi potong daripada jenis-jenis kegiatan rutin, maka dapat dikatakan bahwa pola kemitraan pada usaha sapi potong belum ada. Tampaknya wanita walaupun mempunyai kontribusi yang tinggi terutama pada usaha skala menengah, namun statusnya masih dibilang belum tinggi.

\section{Kegiatan Koperasi dan Penyuluhan}

Kegiatan koperasi dan penyuluhan (Tabel 4) masih didominasi oleh pria. Demikian juga pada pola pengambilan keputusannya. Kondisi ini sangat didukung oleh budaya yang menganggap pria adalah pemimpin keluarga dan pencari nafkah, sehingga kegiatan-kegiatan dan pengambilan keputusan yang berkaitan erat dengan pencarian nafkah diprioritaskan pria. Kegiatan-kegiatan penyuluhan yang diadakan petugas juga hampir selalu hanya melibatkan pria. Hal ini berakibat lanjut kepada rendahnya pengetahuan dan keterampilan wanita pada usaha sapi potong.

Tabel 4. Kegiatan koperasi dan penyuluhan

\begin{tabular}{lcccccc}
\hline Jenis Pekerjaan & \multicolumn{3}{c}{ Skala kecil } & \multicolumn{3}{c}{ Skala menengah } \\
\cline { 2 - 7 } & Pria & Wanita & Pria+Wan & Pria & Wanita & Pria+Wan \\
\hline Kegiatan penyuluhan & 86,21 & 13,79 & - & 84,38 & 15,62 & - \\
Pengambilan kredit & 23,53 & $0 ., 0$ & 85,29 & 30,00 & 0,00 & 70,00 \\
Anggota KUD & 78,79 & 0,00 & 21,21 & 79,31 & 0,00 & 20,69 \\
\hline
\end{tabular}

\section{Pola Pekerjaan Mencari Nafkah}

Usaha sapi potong masih dianggap sebagai usaha sampingan, sementara bertani masih menjadi usaha utama untuk sebagian besar responden. Berdasarkan data pola pengambilan keputusan tersebut, maka dapat diduga bahwa pola pekerjaan mencari nafkah bagi wanita bersifat membantu. Karena bersifat membantu, maka pekerjaan rumah tangga tidak berkurang walaupun kontribusinya dalam mencari nafkah cukup besar. Hal ini menempatkan wanita kepada peran ganda yaitu sebagai ibu rumah tangga dan pencari nafkah. Dengan demikian, wajarlah jika jam kerja wanita lebih banyak daripada pria. Pada kegiatan mata pencaharian utama, wanita juga sangat mempunyai andil yang besar.

\section{Kegiatan Rumah Tangga}

1. Lama pekerjaan rumah tangga (jam/hari) 
Tabel 5 menunjukkan lama pekerjaan rumah tangga. Kegiatan rumah tangga yang rutin ini didominasi oleh wanita. Jam kerja wanita rata-rata 5,889 jam dan untuk pria 0,282 jam pada usaha sapi potong skala kecil. Pada usaha skala menengah, lama pekerjaan rumah tangga untuk wanita 6,402 jam dan pada pria 0,087 jam per hari.

Tabel 5. Lama pekerjaan rumah tangga (jam/hari)

\begin{tabular}{lcccc}
\hline Jenis Pekerjaan & \multicolumn{2}{c}{ Skala kecil } & \multicolumn{2}{c}{ Skala menengah } \\
\cline { 2 - 5 } & $\mathrm{P}$ & $\mathrm{W}$ & $\mathrm{P}$ & $\mathrm{W}$ \\
\hline Mencuci pakaian & 0,055 & 1,413 & 0,017 & 1,333 \\
Mencuci alat dapur & 0,016 & 0,934 & 0,00 & 1,000 \\
Membersihkan halaman & 0,082 & 0,555 & 0,024 & 0,814 \\
Membersihkan rumah & 0,039 & 0,672 & 0,008 & 0,839 \\
Memasak & 0,032 & 1,373 & 0,00 & 1,484 \\
Belanja & 0,058 & 0,942 & 0,038 & 0,932 \\
Jumlah & 0,282 & 5,889 & 0,087 & 6,402 \\
\hline P = Pria, W = wanita & & & &
\end{tabular}

Yang menarik, walaupun kegiatan usaha sapi potong skala menengah jam kerja wanita pada usaha tersebut relatif sama dengan pria, namun jam kerja pada rumah tangga tidak berkurang dan bahkan cenderung meningkat. Sementara naiknya jam kerja pria pada usaha sapi potong menyebabkan turunnya kontribusi pria pada kegiatan rumah tangga. Faktor penyebab timbulnya fenomena ini belum diketahui benar. Hal ini mungkin lebih disebabkan oleh faktor budaya yang menempatkan pria di atas wanita, sehingga ketika terjadi kegiatan wanita disektor usaha meningkat, pria cenderung menekannya dengan memberi jam kerja yang lebih pada kegiatan rumah tangga. Atau faktor sosial-budaya yang menempatkan pria sebagai pencari nafkah dan wanita sebagai pengelola rumah tangga di masyarakat belum berubah walaupun telah terjadi pergeseran fungsi wanita dewasa ini. Yang lebih menarik lagi adalah pada skala kecil justru pria mempunyai kontribusi yang lebih besar daripada skala kecil (Tabel 6). Faktor penyebab timbulnya fenomena tersebut belum diketahui secara pasti.

Tabel 6. Pelaksana pekerjaan pada kegiatan rumah tangga (\%)

\begin{tabular}{lcccccc}
\hline Jenis Pekerjaan & \multicolumn{3}{c}{ Skala kecil } & \multicolumn{3}{c}{ Skala Menengah } \\
\cline { 2 - 7 } & $\mathrm{P}$ & $\mathrm{W}$ & $\mathrm{P}+\mathrm{W}$ & $\mathrm{P}$ & $\mathrm{W}$ & $\mathrm{P}+\mathrm{W}$ \\
\hline Mencuci pakaian & 3,08 & 90,77 & 6,15 & 0,00 & 96,67 & 3,33 \\
Mencuci alat dapur & 1,54 & 96,92 & 1,54 & 0,00 & 100,00 & 0,00 \\
Membersihkan halaman & 3,08 & 81,54 & 15,38 & 0,00 & 87,10 & 12,90 \\
Membersihkan rumah & 0,00 & 89,06 & 10,94 & 0,00 & 93,55 & 6,45 \\
Memasak & 3,08 & 95,38 & 1,54 & 0,00 & 100,00 & 0,00 \\
Belanja & 1,54 & 89,23 & 9,23 & 0,00 & 81,82 & 18,18 \\
Rata-rata & 2,05 & 90,48 & 7,46 & 0,00 & 93,19 & 6,81 \\
\hline
\end{tabular}

$\mathrm{P}=$ Pria, $\mathrm{W}=$ wanita, $\mathrm{P}+\mathrm{W}=$ dikerjakan oleh pria dan wanita 
Tabel 6 menunjukkan pelaksana pekerjaan pada kegiatan rumah tangga. Secara umum, pelaksana kegiatan rumah tangga masih sangat didominasi oleh wanita. Hal ini sangat wajar mengingat lingkungan sosial-budaya dimana tugas utama wanita adalah sebagai pengelola kegiatan rumah tangga. Pria sangat sedikit kontribusinya dalam pekerjaan rumah tangga. Hal ini sesuai dengan sosial budaya setempat yang menempatkan pria sebagai pemimpin keluarga serta sebagai pencari nafkah keluarga sementara wanita adalah pengelola rumah tangga.

Sosial-budaya ini belum berubah sekalipun kontribusi wanita terhadap kegiatan pencari nafkah tinggi. Contohnya walaupun kontribusi wanita skala menengah tinggi sejajar dengan jam kerja pria, namun pada kenyataannya pekerjaan rumah tangga masih merupakan beban wanita. Faktor pendidikan belum bisa ditelaah kontribusinya terhadap status wanita, karena sebagian besar reponden berpendidikan sekolah dasar.

Tabel 7. Perbandingan pengambil keputusan pada kegiatan rumah tangga (\%)

\begin{tabular}{lcccccc}
\hline Jenis Pekerjaan & \multicolumn{3}{c}{ Skala kecil } & \multicolumn{3}{c}{ Skala Menengah } \\
\cline { 2 - 7 } & $\mathrm{P}$ & $\mathrm{W}$ & $\mathrm{P}+\mathrm{W}$ & $\mathrm{P}$ & $\mathrm{W}$ & $\mathrm{P}+\mathrm{W}$ \\
\hline Mencuci pakaian & 3,17 & 84,13 & 12,69 & 0,00 & 93,33 & 6,67 \\
Mencuci alat dapur & 0,00 & 96,87 & 3,13 & 0,00 & 96,67 & 3,33 \\
Membersihkan halaman & 0,00 & 89,06 & 10,94 & 0,00 & 87,09 & 12,90 \\
Membersihkan rumah & 0,00 & 90,62 & 9,38 & 0,00 & 93,55 & 6,45 \\
Memasak & 0,00 & 87,30 & 12,70 & 0,00 & 90,32 & 9,68 \\
Belanja & 3,08 & 58,46 & 38,46 & 3,03 & 54,54 & 42,42 \\
Rata-rata & 1,04 & 84,41 & 14,55 & 0,51 & 85,92 & 13,58 \\
\hline P=Pia,
\end{tabular}

$\mathrm{P}=$ Pria, $\mathrm{W}=$ wanita, $\mathrm{P}+\mathrm{W}=$ dikerjakan oleh pria dan wanita

Tabel 7 menunjukkan perbandingan pengambil keputusan pada kegiatan rutin rumah tangga. Seperti yang telah diduga bahwa pengambil keputusan kegiatan rumah tangga masih didominasi oleh wanita. Yang menarik adalah bahwa pengambil keputusan kegiatan belanja untuk keperluan sehari-hari dilakukan secara bersama-sama $(38,46 \%$ untuk skala kecil dan 42,42 untuk skala usaha menengah). Ini sangat menarik, mengingat belanja itu berkaitan dengan pengeluaran uang.

Tabel 8 menunjukkan pola pengambilan keputusan kegiatan rumah tangga yang lain. Pada jenis-jenis kegiatan ini, walaupun wanita masih mendominasi kegiatan rumah tangga, priapun secara bersama-sama dengan wanita melakukan kegiatan tersebut. Kegiatan mendidik anak, pemegang keuangan, bermain dengan anak, pembelian pakaian dan perlengkapan rumah, perbaikan rumah dan pengaturan keuangan diputuskan secara bersama-sama. Ini menunjukkan bahwa pria sebagai pemimpin keluarga sangat berperan pada kegiatan rumah tangga yang berkaitan erat dengan kelangsungan hidup dan pendidikan anggota keluarga dan keuangan keluarga. Dalam penelitian ini belum terungkap jumlah uang yang dikelola wanita (isteri) dan pria (suami). 
Tabel 8. Pola pengambilan keputusan kegiatan rumah tangga yang lain (\%)

\begin{tabular}{lcccccc}
\hline \multirow{2}{*}{ Jenis Pekerjaan } & \multicolumn{3}{c}{ Skala kecil } & \multicolumn{3}{c}{ Skala menengah } \\
\cline { 2 - 7 } & $\mathrm{P}$ & $\mathrm{W}$ & $\mathrm{P}+\mathrm{W}$ & $\mathrm{P}$ & $\mathrm{W}$ & $\mathrm{P}+\mathrm{W}$ \\
\hline Mengasuh anak & 0,00 & 69,39 & 30,61 & 0,00 & 72,22 & 27,78 \\
Mendidik anak & 6,25 & 4,69 & 89,91 & 9,68 & 12,90 & 77,42 \\
Pemegang keuangan & 23,81 & 9,52 & 66,67 & 31,03 & 10,34 & 58,62 \\
Memandikan anak & 0,00 & 90,48 & 9,52 & 4,76 & 85,71 & 9,52 \\
Memberikan makan dan & 0,00 & 94,34 & 5,66 & 0,00 & 95,45 & 4,54 \\
minum & & & & & & \\
Bermain dengan anak & 0,00 & 27,87 & 72,13 & 0,00 & 19,23 & 80,77 \\
Mengatur rumah dan & 0,00 & 71,43 & 28,57 & 0,00 & 65,63 & 34,38 \\
pekarangan & & & & & & \\
Pembelian pakaian & 9,38 & 17,19 & 73,44 & 15,63 & 9,38 & 75,00 \\
Pembelian perlengkapan & 5,97 & 4,48 & 89,55 & 21,21 & 0,00 & 78,79 \\
rumah & & & & & & \\
Perbaikan rumah & 37,31 & 1,49 & 61,19 & 56,25 & 0,00 & 43,75 \\
Pembelian alat dapur & 2,99 & 74,63 & 22,39 & 6,06 & 72,73 & 21,21 \\
Pengatur keuangan & 14,71 & 25,00 & 60,29 & 12,50 & 31,25 & 56,25 \\
Rata-rata & 8,37 & 40,88 & 50,83 & 13,93 & 39,57 & 47,34 \\
\hline P = Pria, W = wanita, P+W = dikerjakan oleh pria dan wanita & & & & \\
\end{tabular}

Secara umum, keputusan wanita untuk melakukan suatu pekerjaan selalu dibayangi oleh suatu pikiran apa yang disenangi oleh pria (suami), sehingga walaupun pada faktanya keputusan dilakukan oleh wanita, tetapi secara psikologis selalu mempertimbangkan keinginan pria (suami). Sementara pola pengambilan keputusan pria bersifat mandiri tanpa memasukkan keinginan wanita. Dengan demikian dominasi pria pada pola pengambilan keputusan kegiatan usaha sapi potong dan kegiatan-kegiatan rumah tangga yang dianggap penting masih sangat kuat. Mengingat tingginya kontribusi wanita pada usaha sapi potong dan rumah tangga, maka peningkatan ilmu pengetahuan dan keterampilan wanita sangat penting serta merubah status wanita dari sebagai "Konco wingking" menjadi mitra bisnis.

Dengan cara ini produktivitas sapi potong dan kaulitas generasi penerus akan meningkat. Jadi,wanita mempunyai peran ganda yang penting dalam keluarga yaitu sebagai ibu rumah tangga sekaligus sebagai pencari nafkah (Puspitawati et al., 2012).

\section{KESIMPULAN}

Dapat disimpulkan bahwa kontribusi wanita pada usaha sapi potong adalah tinggi, namun statusnya masih dianggap sebagai pembantu pria sebagai pencari nafkah. Hal ini disebabkan oleh sosial-budaya dan agama setempat yang menempatkan pria sebagai pemimpin keluarga dan sebagai pencari nafkah dan wanita sebagai pengelola rumah tangga.

\section{DAFTAR PUSTAKA}

Alatas, S. 1990. The effect of change in life cycle strage on the migration behavior ofindividuals in Javanese 
communities in ndonesia. $\mathrm{PhD}$ Disertation. Brown University.

Annisawati, K. Muatip dan N. N. Hidayat. 2014. Curahan tenaga kerja perempuan dalam usaha ternak sapi Jabres di Kabupaten Brebes. Jurnal Ilmiah Peternakan, 2: 94101.

Fatmawati. 2011. Kontribusi curahan kerja wanita pada usaha peternakan kelinci, di kelurahan salokaraja, kecamatan lalabata, kabupatensoppeng. Skripsi Jurusan Sosial Ekonomi Peternakan, Fakultas Peternakan, Universitas Hasanuddin. Makassar.

Gusmaniar. 2013. Kontribusi pendapatan wanita peternak kelinci terhadap total pendapatan keluarga di Kelurahan Salokaraja Kecamatan Lalabata Kabupaten Soppeng. Skripsi. Universitas Hasanuddin, Makasar.

Hugeng, S. 2011. Alokasi waktu kerja dan kontribusi perempuan terhadap pendapaan keluarga di permukiman transmigrasi Sei Rmbutan SP2. Jurnal Ketramsmigrasian, 28: 125-134.

Kumala, P. 2011. Kontribusi Pendapatan Nelayan Terhadap Pendapatan Keluarga Di Tokolan Desa Batang Tumu Kecamatan Mandah Kabuaten Indragiri Hilir. Program Studi Pendidikan Ekonomi Fakultas Keguruan dan Ilmu Pendidikan Universita Riau, Riau.
Larasati, U. 2003. Pengaruh Alokasi Waktu Perempuan Terhadap Pendapatan Perempuan. Program Studi Magister Ekonomi Pembangunan. Tesis tidak diterbitkan. Yogyakarta: PPS Universitas Gajah Mada.

Lestariningsih, M., Basuki dan Y. Endang. 2008. Peranserta wanita peternak sapi perah dalam meningkatkan taraf hidup keluarga. Ekuitas, 12: 121-141.

Levy, M.J.1971. The family revolution in modern China. Octagan Books, New York.

Mahdalia, A. 2012. Kontribusi curahan waktu kerja perempuan terhadap total curahan waktu kerja pada usaha peternakan sapi potong di perdesaan (Studi Kasus, Kelompok Tani Ternak Lonrae Kelurahan Samaenre Kecamatan Sinjai Tengah Kabupaten Sinjai). Universitas Hasanuddin, Makassar.

Puspitawati, H., M. Simanjuntak dan L. Hayati.2012. Kontribusi ekonomi dan peran ganda perempuan serta pengaruhnya terhadap kesejahteraan subjektif. Jur. Ilm. Kel. \& Kons., 5 (1): 11-18.

Sajogyo, P. 1983. Partisipasi masyarakat desa dalam pembangunan pertanian, khususnya menyoroti partisipasi wanita dalam proses pembangunan pertanian. Makalah pada seminar IKIP Jakarta, Jakarta. 
Sajogyo, P. 1984. Wanita dan kerja. Hasil penelitian di pedesaan Jawa Barat dan beberapa daerah di luar Jawa. Makalah pada seminar nasional wanita. Fakta dan Citra, Jakarta.

Utomo, B, Sarjana dan Pertiwi, D. 2007. Kontribusi Usaha Sapi Perah terhadap Pendapatan Rumah Tangga Peternak: Studi Kasus di Desa Kembang,Kabupaten Boyolali. Balai Pengkajian Teknologi Pertanian. Jawa Tengah.

Wahyuni, S.1983. Women's Involvement in Small Ruminant Production in Cirebon West Java. Working
Papers, No. 14. Centre Research Instute of Anim. Sci., Bogor.

Wigna, W., Krisnawati dan White, B. 1980. Comparison of the result of time allocation research using two different recall period. Survey Agro Economic, Bogor.

Wisadirana, D. 1986. Kesempatan kerja wanita tani dalam usaha peternakan sapi perah rakyat di Pujon Malang. Hasil penelitian kerjasama antar IKIP Malang dengan Yayasan Ilmu-ilmu Sosial (YIIS) Jakarta. Pusat Penelitian IKIP Malang. 